\title{
EXPLORING THE L2 MOTIVATIONAL SELF SYSTEM IN SPAIN: STUDY DESIGN AND PRELIMINARY FINDINGS
}

\author{
Imelda Katherine BRADY \\ Centro Universitario de la Defensa, Universidad Politécnica de Cartagena \\ Imelda.brady@cud.upct.es
}

\begin{abstract}
This paper details the design and validation of a Motivational Factors Questionnaire (MFQ) used to explore the L2 Motivational Self System (L2MSS) (Dörnyei 2009) of over 500 Spanish learners of English. The mixed methods Spanish study was a partial replica of Ryan (2009) in Japan and Taguchi, Magid and Papi (2009) in Asia. The final validated version of the MFQ we present here thus contains 67 items comprising 13 psychometric scales targeting the ideal L2 self, the ought L2 self, as well as a diverse range of goal-related and affective motivational variables. We were able to confirm that the ideal L2 self is a relevant construct for the sample although the ought L2 self emerged as having a negative relationship with L2 learning. The L2 learning experience was explored in this study from the perspective of past L2 learning in compulsory education and we ascertained somewhat negative opinions in this regard.
\end{abstract}

Keywords: L2 motivation, ideal self, ought self, international posture, Motivational Factors Questionnaire. 


\title{
ANÁLISIS DEL SISTEMA MOTIVACIONAL DEL YO L2 EN ESPAÑA: DISEÑO DEL ESTUDIO Y RESULTADOS INICIALES
}

\begin{abstract}
RESUMEN. El presente artículo detalla el diseño y los procedimientos seguidos para la validación de un Cuestionario de Factores Motivacionales (CFM) para aplicar la teoría del Sistema Motivacional del Yo L2 (SMY L2) (Dörnyei 2009) en España. El estudio realizado con 529 estudiantes universitarios constituye una réplica de Ryan (2009) y Taguchi, Magid y Papi (2009). El cuestionario está compuesto de 67 items distribuidos en 13 escalas psicométricas que miden factores como el ideal del yo L2, el yo deóntico L2 y otros variables motivacionales relacionados con las metas y los valores afectivos. Pudimos confirmar que el ideal del yo L2 es una figura relevante para la muestra mientras que el yo deóntico L2 resultó tener una relación negativa con el aprendizaje de la L2. Nuestro análisis de las experiencias pasadas de aprendizaje de la L2 fue fructífero ya que pudimos detectar cierta negatividad en esta variable actitudinal.
\end{abstract}

Palabras clave: motivación, aprendizaje L2, ideal del yo, el yo deóntico, perspectiva internacional, Cuestionario de Factores Motivacionales.

Received 28 February 2018

Revised version accepted 17 October 2018

\section{INTRODUCTION}

This paper details the design and validation of a Motivational Factors Questionnaire (MFQ) created to explore the tenets of the L2 Motivational Self System (Dörnyei 2005, 2009) in Spain. The MFQ was administered to 529 undergraduates in the Region of Murcia as part of a mixed methods thesis study (Brady 2015). Currently, at this early stage of the application of L2 MSSS theory in language learning contexts in Europe (see Boo, Dörnyei and Ryan 2015, for an overview of recent L2 motivation studies), some qualitative work is being carried out on the practical applications of the L2 Motivational Self System in Spain (e.g. Mackay 2014) yet the L2 MSS has been applied quantitatively in few large-scale explorations on mainland Spain, making the study described in this paper a pioneering one in the application of the L2 Motivational Self System to gain insight into the language learning attitudes and behaviour in population of students in south-eastern Spain. To carry out the study exploring the existence and nature of the ideal and ought L2 selves in Spain, we employ an extended Spanish version of a Motivational Factors Questionnaire (MFQ) based on the original L2 MSS validation studies of Ryan (2009) in Japan and Taguchi, Magid and Papi (2009) in Japan, China and Iran, respectively. The final piloted Spanish MFQ included 13 psychometric scales among which feature an instrumentality promotion-prevention measure as well as a scale to explore the novel orientation of international posture (Yashima 2000, 
2002, 2009). Although, most L2 MSS studies (e.g. Busse 2010, 2013; Busse and Williams 2010; Csizér and Lucáks 2010; Henry 2011; Islam, Lamb and Chambers 2013; Kormos and Csizér 2008; Kormos, Kiddle and Csizér 2011; Lamb 2012; You and Dörnyei 2016) have employed parts of the original MFQs used by Ryan and Taguchi et al. to a greater or lesser extent, the Spanish MFQ can be considered quite a comprehensive instrument in that it incorporates self-related, goal-related and affective factors as well as the three pillars of the L2 MSS as conceptualised by Dörnyei (2005, 2009).

\section{THE L2 MOTIVATIONAL SELF SYSTEM}

It is not the scope of this article to provide more than a brief overview of the main tenets of the L2MSS (see Dörnyei and Ushioda 2009 for a detailed debate on the theoretical and practical applications). Dörnyei (2005, 2009a) proposes the construct of the L2 Motivational Self System (L2 MSS) based on possible selves' theory in mainstream psychology (Markus and Nurius 1987) and Higgins' selfdiscrepancy theory (1987), This broad framework of L2 learning incorporates an ideal L2 self, an ought L2 self, and the further dimension of the L2 learning experience.

Under Dörnyei's conceptualisation, the ideal L2 self encapsulates the imaginings or visions one may have of oneself using the foreign language in the future. Dörnyei claims that learners may have imagined L2 selves that are proficient in the L2 and, in his view this phenomenon may explain L2 motivated behaviour more precisely than the renowned concept of integrativeness. Gardner and Lambert's (1972) and Gardner (1985) conceptualisation denoted a desire to become closer and even similar to the community of speakers of the L2 in question and this construct became the most cited precursor to motivated language learning behaviour for almost half a decade. Dörnyei (2009), however, in questioning the prevalence of a desire for integration in contexts very distanced from native speaker communities (e.g. Hungary) conjectured that a future L2 self-guide formed through the experiences, hopes and desires of the learner becomes an imagined L2 ideal that the learner will seek to emulate. Under the ideal L2 self-conceptualisation, the target vision or ideal transcends a sense of positive identification with a native speaker community along with the negative connotations that becoming closer to that community involved distancing oneself from one's own community somehow having to compromise current relationships in order to leave space for the new one. As a more open and flexible framework for L2 motivation, the ideal L2 self construct also facilitates the incorporation of positive instrumental motives, such as improving employment opportunities, becoming a more knowledgeable 
person and so on - important pragmatic rationales behind L2 learning that had mistakenly become dichotomous with the integrative motive. The imaginary figure of an ideal L2 self has proved readily identifiable and effective in participants in L2 MSS studies in different cultural contexts with some variation in terms of detail and energising force depending perhaps on factors such as age (e.g. Huang and Chen 2017; Chen, Warden and Huang 2005; Kormos and Csizér 2008) and learning style (e.g. Kim and Kim 2011).

The L2 ought self, on the other hand, was conceptualised as representing extrinsic influences on the self and so incorporates social pressures and obligations or duties related to knowledge of the L2 imposed by external social groups or entities - for instance, the foreign language related ideals that parents, teachers and significant others have for their loved ones and protégés. Another facet of the L2 ought self may come from the fear of what one may become in life without L2 competence. Dörnyei (2009) here draws a parallel between the ought L2 self and negative instrumental motivation - the preventative act of avoiding negative outcomes (Higgins 1998), e.g. failing to live up to expectations or getting low exam marks. It is the case that that with the exception of Taguchi et al. (2009), most studies on the components of the L2 MSS have found the ought L2 self difficult to detect in terms of an externally-configured energising effect on L2 motivation (e.g. Kormos and Csizér 2008). Debate has ensued on whether a sense of external obligation might be internalised by L2 learners and intrinsic to the L2 self-guide (e.g. Lamb 2012; You and Dörnyei 2016) or, given its existence in some Asian studies, whether the influence of significant others on ones' desire to learn a foreign language might be culture specific.

The third cornerstone of the construct, the L2 learning experience, somewhat inexplicit within the L2 MSS construct in contrast with the more detailed L2 selves, involves situation specific motives related to the immediate learning environment and experience. This dimension of the theory is conceptualised "at a different level from the two self guides" (Dörnyei 2009: 29) and is specific to foreign language learning contexts. The experiential angle of L2 learning has no precedent in mainstream psychology research on the self and its role within the L2 MSS or indeed the elements it comprises still require theoretical and empirical attention. The L2 learning experience, past and/or present that Dörnyei feels contributes specifically to the configuration and energising effect of L2 possible selves could encompass a plethora of aspects related to informal or formal learning-from the teacher to the learner group to classroom methodology and materials. In most L2 MSS studies, explorations of the learning experience have involved direct reference to the L2 classroom, (e.g. Kormos and Csizér 2008; Ryan 2009; Taguchi et al. 2009) and informal learning outside the classroom (Lamb 2012). In this study 
the focus chosen for further exploration of the learning experience was temporal distinguishing past form current learning attitudes.

\section{MIXED METHODS RESEARCH}

Recent post-structuralist views on L2 motivation have brought the individual and his or her multidimensional capacity for interaction and negotiation within the social environment to the fore (e.g. Kanno and Norton 2003). Some researchers question the utility of quantitative methods to examine cross sections of the population given that, as Ushioda (2009: 215) argues, motivation, being variable and individual, is difficult to fully investigate through numerical data. In other words, statistical procedures that establish linear causal relations and 'neutralize' the data cannot fully reflect the multidimensionality of motivation or the complex, idiosyncratic dynamics of such an intricate attribute. For those unexperienced in the newer qualitative methods, however, Dörnyei and Ushioda (2011: 241) contend that mixing methods allows one to achieve an elaborate and comprehensive understanding of a complex matter by enabling the researcher to examine the phenomenon from different angles.

The study herein described proposed to examine L2 motivation in a college student population through a mixed methods design similar to that used in Ryan (2008), which can be represented as follows:

The qual - quan - qual structure (Fig. 1), which was originally devised by Morse (1991, 2003, in Ryan 2008), indicates that although priority is given in weight to the quantitative data, this phase is complemented and enriched by qualitative phases enabling the researcher to access contextual and interpretative data based on the quan findings.

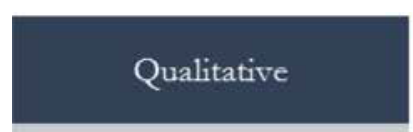

- Exploratory interviews
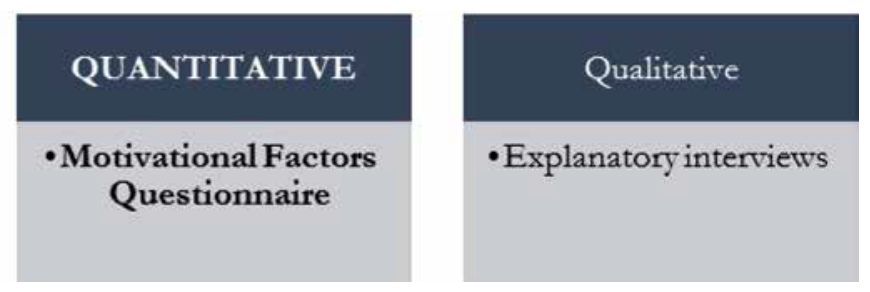

Figure 1. Mixed methods study structure.

The main data collection instrument in the quan phase of our study is a Motivational Factors Questionnaire (MFQ). Prior to the design of the MFQ, in the initial qualitative phase, interviews were carried out in order to able to gain 
insights from learners into potential contextual variables regarding the ideal and ought L2 self dimensions of the construct. A further aim of this phase was to explore the terminology participants would use in Spanish when making reference to these newer theoretical paradigms and so inform the translation process.

The post MFQ qual phase of the study was designed to resolve possible ambiguities in the interpretation of the quan findings and, in this case, it was used to examine the ought L2 self in more detail (See RQ 2 below). This phase involved semi-structured interviews with two teacher trainees to investigate their attitudes to the recent governmental obligation for teachers in compulsory education to certify L2 skills in order to teach in bilingual schools.

\section{THE MOTIVATIONAL FACTORS QUESTIONNAIRE}

The original Motivational Factors Questionnaire (MFQ) (Ryan 2008, 2009) was used in the first empirical exploration to test the L2 MSS tenets against the long-standing concept of integrativeness (Gardner 1985). Ryan's MFQ contained psychometric scales targeting the novel concepts of the ideal L2 self, international posture and ethnocentrism, which were pertinent to his research questions. He also replicated the relevant variables used in the Hungarian studies by Dörnyei and colleagues (e.g. Csizér and Dörnyei 2005a, 2005b; Dörnyei and Clément 2001). On the other hand, the MFQs used in Taguchi et al. (2009) in the Asian contexts of China, Japan and Iran had been adapted for the idiosyncrasies of each geographical and cultural context. For instance, a particular aim in Taguchi et al. (2009) was to explore the ought L2 self in more depth as this cornerstone of the L2 MSS at that time had not been empirically tested. Table 1 shows all the motivational variables used in the two Asian studies on the L2 MSS as well as the variables chosen for the pilot study in Spain.

We examined these MFQ scales and items against the specific RQs posed for the Spanish study. Our overarching aim was to see what the L2 MSS could tell us about the English language learning attitudes and behaviour of a Spanish university population in the light of reports (e.g. English First Proficiency Index 2014, 2015) situating Spain quite low in the EU ranking in terms of L2 achievement. Our specific questions were:

RQ1: How might the ideal L2 self profile differ in students who have chosen English as a major line of study at university in contrast to those in nonEnglish major studies?

RQ2: Given the recent governmental obligation for primary and secondary teachers to certify L2 skills, what role does the ought L2 self profile play in the students 
EXPLORING THE L2 MOTIVATIONAL SELF SYSTEM IN SPAIN...

Table 1. Motivational scales used in previous L2 MSS studies.

\begin{tabular}{|c|c|c|c|}
\hline Ryan (2009) & $\begin{array}{l}\mathbf{N}^{\circ} \text { of } \\
\text { items }\end{array}$ & $\begin{array}{c}\text { Taguchi, Magid and Papi } \\
\text { (2009) }\end{array}$ & $\begin{array}{l}\mathbf{N}^{\mathbf{o}} \text { of } \\
\text { Items** }\end{array}$ \\
\hline INTENDED LEARNING EFForT & 8 & InTENDED LEARNING EFForT & $4 / 6 / 6$ \\
\hline 1. Ideal Self & 6 & 1. IdEAL SELF & $5 / 5 / 6$ \\
\hline 2. Cultural Interest & 6 & 2. Cultural Interest & $4 / 3 / 4$ \\
\hline \multirow[b]{2}{*}{ 3. Attitude to the L2 COMmUnity* } & \multirow[b]{2}{*}{8} & 3. Ought Self & $4 / 7 / 6$ \\
\hline & & $\begin{array}{l}\text { 4. ATtITUDE TOWARDS THE L2 } \\
\text { COMMUNITY } \\
\text { 5. INTEGRATIVENESS }\end{array}$ & $4 / 4 / 4$ \\
\hline 4. InSTRUMENTALITY & 10 & $\begin{array}{l}\text { 6. Instrumentality Promotion } \\
\text { 7. InStrumentality PreVEntion }\end{array}$ & $\begin{array}{l}5 / 8 / 6 \\
5 / 5 / 8\end{array}$ \\
\hline 5. INTERNATIONAL EMPATHY & 3 & $\ldots$ & \\
\hline 6. INTERNATIONAL CONTACT & 4 & $\ldots$ & $\ldots$ \\
\hline 7. INTEREST IN FOREIGN LANGUAGES & 5 & $\ldots$ & $\ldots$ \\
\hline 8. Fear of Assimilation & 4 & $\ldots$ & $\ldots$ \\
\hline 9. ETHNOCENTRISM & 5 & $\ldots$ & \\
\hline 10. Travel orientation & 4 & $\ldots$ & $\ldots$ \\
\hline 11. English Use Anxiety & 6 & $\ldots$ & \\
\hline 12. Attitudes to learning ENGLish & 6 & 8. Attitudes to LEARNiNg ENGLish & $4 / 4 / 6$ \\
\hline 13. Milieu & 6 & & \\
\hline 14. Parental encouragement & 4 & 9. FAMILY inFLUENCE & $4 / 5 / 6$ \\
\hline 15. L2 Self-Confidence & 5 & $\ldots$ & $\ldots$ \\
\hline $\begin{array}{l}\text { 16. WiLLINGNESS TO COMMUNICATE (IN } \\
\text { ENGLISH/IN JAPANESE) }\end{array}$ & $8(x 2)$ & $\ldots$ & $\ldots$ \\
\hline TOTAL ITEMS & 106 & & $39 / 47 / 52$ \\
\hline
\end{tabular}

*In Ryan, items targeting the concept of integrativeness were embedded in the scale of Attitude to L2 community.

*** In order of Taguchi (Japan)/Magid (China)/Papi (Iran). 
in education related studies at university in contrast to those involved in studies unrelated to education?

RQ3: What role do L2 learning experiences play in the L2 motivational behaviour and attitudes of university students in Murcia?

RQ4: What role do the different attitudinal, goal-related and affective variables play in the motivational make-up of the sample?

RQ5. How does the motivational make-up of the sample differ according to variables of a) perceived proficiency in English and b) gender?

An initial pre-selection of scales was made based the above RQs. The intention was to produce a MFQ that could be as precise as possible in measuring the L2 MSS tenets, yet as broad and flexible as possible to facilitate integration of other motivational variables. However, considerations of questionnaire length (Dörnyei 2010) as well as issues of the cultural relevance of certain variables also had to be taken into account.

A series of semi-structured interviews were carried out with nine volunteer participants from diverse college degrees. The interviews were conducted entirely in Spanish and lasted between 30 and 40 minutes. The data enabled us to confirm existence of a future L2 self vision along with sufficient evidence to confirm the inclusion of many of the various motivational variables pre-selected for the MFQ. Some cultural differences were apparent, meaning that adjustments were required for the wording of some items. To give an example, one particular linguistic change was introduced with reference to family and significant others. When referring to encouragement or pressure from these sources to learn English, the Asian studies had used the term 'respect' e.g. 'Studying English is important to me because the people I respect think that I should do it' (Taguchi et al. 2009: 92). However, the term 'respect' had not come up repeatedly in any of the interviews; instead the more emotive terms of 'love' or 'care about' emerged more often when referring to family members and their influence on L2 learning. Therefore, this item was changed to Quiero aprender inglés porque mis seres queridos piensan que es importante (I want to learn English because my loved ones consider it important).

Regarding social influences and engagement in learning English, the interviewees expressed a sense of responsibility to learn English for various reasons, e.g. the advantages for employment and travel or the need for English to gain knowledge about the world. Some participants expressed interest in interacting with nonnative L2 speakers, giving the perception that a more international outlook on English as a lingua franca could be a relevant concept in Spain. Thus, for instance, we felt justified in including a scale on international posture. 
All in all the interviews facilitated the understanding that the newer concepts of envisaging a future ideal L2 self and a sense of obligation to learn through the ought L2 self seemed relevant to this population. A further advantage of the qualitative interview phase was the linguistic references in discussing on the MFQ concepts in Spanish, therefore providing insights for the translation process. Table 2 presents some of the modifications.

Table 2. Examples of rewording and/or translation of some scale items.

\begin{tabular}{|c|c|c|}
\hline SCALE & $\begin{array}{c}\text { EXAMPLE ORIGINAL } \\
\text { ITEM } \\
\text { (R = Ryan, } \mathbf{T}=\text { Taguchi })\end{array}$ & $\begin{array}{l}\text { REWORDING } \\
\text { /TRANSLATION }\end{array}$ \\
\hline IdEAL SeLf: & $\begin{array}{l}\text { If my dreams come true, I } \\
\text { will use English effectively } \\
\text { in the future (R) }\end{array}$ & $\begin{array}{l}\text { I dream about being fluent in English } \\
\text { Sueño con dominar el inglés }\end{array}$ \\
\hline Ought Self: & $\begin{array}{l}\text { My parents believe that I } \\
\text { must study English to be } \\
\text { an educated person (T) }\end{array}$ & $\begin{array}{l}\text { My parents think I should make an effort } \\
\text { to improve my English } \\
\text { Mis padres piensan que debo esforzarme } \\
\text { para mejorar mi inglés }\end{array}$ \\
\hline $\begin{array}{l}\text { CURRENT ATTITUDES } \\
\text { TO LEARNING }\end{array}$ & $\begin{array}{l}\text { I am always looking } \\
\text { forward to my English } \\
\text { classes (R) }\end{array}$ & $\begin{array}{l}\text { I usually enjoy English lessons } \\
\text { Yo normalmente disfruto en una clase de } \\
\text { inglés }\end{array}$ \\
\hline Cultural Interest: & $\begin{array}{l}\text { Do you like Hollywood } \\
\text { films? (R) }\end{array}$ & $\begin{array}{l}\text { I like watching films in their original } \\
\text { English version } \\
\text { Me gusta ver películas en versión original } \\
\text { en inglés }\end{array}$ \\
\hline $\begin{array}{l}\text { INSTRUMENTALITY } \\
\text { PREVENTION: }\end{array}$ & $\begin{array}{l}\text { Studying English is } \\
\text { important to me because } \\
\text { without passing the } \\
\text { English course I cannot } \\
\text { graduate }(\mathrm{T})\end{array}$ & $\begin{array}{l}\text { If I don't learn English, I cannot work at } \\
\text { what I want. } \\
\text { Si no aprendo inglés, no podré trabajar en } \\
\text { lo que quiero. }\end{array}$ \\
\hline INTEGRATIVENESS: & $\begin{array}{l}\text { Would you like to } \\
\text { become similar to people } \\
\text { of English speaking } \\
\text { countries? (R) }\end{array}$ & $\begin{array}{l}\text { I would like to be more similar to British } \\
\text { people } \\
\text { Me gustaría parecerme más a la gente de } \\
\text { la cultura británica }\end{array}$ \\
\hline $\begin{array}{l}\text { INTERNATIONAL } \\
\text { POSTURE: }\end{array}$ & $\begin{array}{l}\text { I would like to be able } \\
\text { to use English to get } \\
\text { involved with people from } \\
\text { other countries (R) }\end{array}$ & $\begin{array}{l}\text { I like to meet people from non-English } \\
\text { speaking countries } \\
\text { Me gusta conocer a gente de países no } \\
\text { anglófonos }\end{array}$ \\
\hline
\end{tabular}




\begin{tabular}{|l|l|l|}
\hline $\begin{array}{l}\text { LANGUAGE USE } \\
\text { AnXIETY: }\end{array}$ & $\begin{array}{l}\text { I would get tense if a } \\
\text { foreigner asked me for } \\
\text { directions in English (R) }\end{array}$ & $\begin{array}{l}\text { I would get tense if a foreigner asked me } \\
\text { for directions in English } \\
\text { Si un extranjero me pidiese direcciones en } \\
\text { inglés, me pondría muy nervioso/a }\end{array}$ \\
\hline L2 SELF-EFFICACY & $\begin{array}{l}\text { I am sure I will be able to } \\
\text { learn a foreign language } \\
\text { (R) }\end{array}$ & $\begin{array}{l}\text { I find it quite easy to learn English } \\
\text { Tengo facilidad para el aprendizaje de } \\
\text { inglés }\end{array}$ \\
\hline PARENTAL & $\begin{array}{l}\text { My parents believe it is important to } \\
\text { spend time abroad to improve one's } \\
\text { English } \\
\text { Mis padres piensan que es importante } \\
\text { pasar una temporada en el extranjero } \\
\text { para mejorar el inglés }\end{array}$ \\
\hline
\end{tabular}

Regarding the criterion measure of motivated behaviour against which to explore the motivational variables selected, a scale of learners' intentions to expend effort in L2 learning in the future — intended learning effort — established by both Ryan (2009) and Taguchi et al. (2009) was selected for use in this Spanish study. Table 3 below outlines the psychometric scales chosen and so as to facilitate the MFQ structure, despite a certain degree of conceptual overlapping we have grouped the variables into a) L2 MSS variables b) attitudinal variables c) goalrelated variables and d) affective factors. ]

Table 3. Scales used in the piloting phase of the MFQ in Spain.

\begin{tabular}{|c|c|}
\hline \multicolumn{2}{|r|}{ CRITERION MEASURE } \\
\hline 0 & $\begin{array}{l}\text { INTENDED LEARNING EFFORt: } 6 \text { items targeting students' past and present learning } \\
\text { activities and their intention to continue study or spend time abroad to improve } \\
\text { their English. }\end{array}$ \\
\hline \multicolumn{2}{|r|}{ L2 MSS factors } \\
\hline 1 & $\begin{array}{l}\text { IDEAL SELF: } 5 \text { items aimed at participants' emotional involvement with the L2 and } \\
\text { visions of themselves using English in the future. }\end{array}$ \\
\hline 2 & $\begin{array}{l}\text { Ought Self: } 4 \text { items targeting the pressure students feel to learn from society, } \\
\text { parents, and significant others. }\end{array}$ \\
\hline 3 & Attitudes to Learning English: 3 items on present attitudes to L2 learning. \\
\hline 4 & $\begin{array}{l}\text { ATTITUDES TO PAST L2 LEARNING: } 4 \text { items on attitudes to learning in compulsory } \\
\text { education. }\end{array}$ \\
\hline
\end{tabular}




\begin{tabular}{|c|c|}
\hline \multicolumn{2}{|r|}{ ATTITUDINAL FACTORS } \\
\hline 5 & $\begin{array}{l}\text { CultuRAl INTEREST: } 4 \text { items targeting the extent to which student watched TV, read, } \\
\text { or listened to music in the L2. }\end{array}$ \\
\hline 6 & $\begin{array}{l}\text { Interest In The English Language: } 6 \text { items targeting students' opinions on the } \\
\text { language itself e.g. structure and sound. }\end{array}$ \\
\hline \multicolumn{2}{|r|}{ GOAL RELATED FACTORS } \\
\hline 7 & $\begin{array}{l}\text { Instrumentality PREVENTION: } 5 \text { items covering a range of disadvantages to not } \\
\text { succeeding in English. }\end{array}$ \\
\hline 8 & $\begin{array}{l}\text { Instrumentality PROMOTION: } 5 \text { items covering a range of pragmatic advantages to } \\
\text { acquiring English. }\end{array}$ \\
\hline 9 & $\begin{array}{l}\text { INTEGRATIVENESS: } 7 \text { items (used in the original Hungarian study) targeting students' } \\
\text { interest in engagement with in UK/US people and their culture. }\end{array}$ \\
\hline 10 & $\begin{array}{l}\text { INTERNATIONAL POSTURE: } 6 \text { items on views of using English in contexts unrelated to } \\
\text { specific native speaker communities. }\end{array}$ \\
\hline 11 & $\begin{array}{l}\text { ETHNOCENTRISM: } 6 \text { items on participants' impressions on Spanish culture and its } \\
\text { language in comparison to other cultures. }\end{array}$ \\
\hline \multicolumn{2}{|r|}{ AFFECTIVE FACTORS } \\
\hline 12 & $\begin{array}{l}\text { LANGUAGE UsE ANXIETY: } 5 \text { items on emotional aspects of using English in the } \\
\text { classroom or in public. }\end{array}$ \\
\hline 13 & $\begin{array}{l}\text { L2 SELF-EFFICACY } 5 \text { items on ease of learning and using opportunities to speak } \\
\text { English. }\end{array}$ \\
\hline 14 & $\begin{array}{l}\text { Parental Encouragement: } 4 \text { items directed at the influence of parents on learning } \\
\text { history and current efforts to learn. }\end{array}$ \\
\hline
\end{tabular}

\section{PILOT STUDY}

\subsection{MFQ ADMINISTRATION}

All the questionnaires were administered by the author of this study during college lectures to 137 college students from a diverse range of degrees. Students were informed that the survey was about attitudes to learning English and that participation was voluntary. Only one student declined to take part. All participants were of Spanish nationality as any exchange students were asked to refrain from filling in the questionnaire. The questionnaires took approximately 25-35 minutes 
to complete. During data cleaning, a total of 13 cases were eliminated from the dataset owing to errors in data entry or irregular patterns of responses, leaving a final total of 124 cases for pilot study analysis. The number of missing responses was under $1 \%$ so it is assumed there were no systematic missing values (Pallant 2007) - a positive indicator in a pilot study indicating that items were not causing extreme confusion or dealing with sensitive information.

\subsection{SCALE RELIABILITY}

The reliability or internal consistency of a scale refers to the extent to which the composite items of the scale are consistent in measuring the underlying construct (Pallant 2007) and one of the most commonly used statistical measurements of this is Cronbach's alpha coefficient. The recommended internal consistency of a scale is $\alpha=.70$, with figures below this indicating that the interpretations of the items by participants in a study may not be as consistent as they should or that the items are not measuring the same concepts. The calculation of a scale's consistency, however, can be sensitive to the number of items that make up the scale and in this sense Pallant (2007) suggests that a scale containing fewer than ten items can often have a lower yet acceptable Cronbach value. Table 4 shows the internal consistency of the scales that did not reach the recommended alpha value of 0.70 .

Table 4. Scales obtaining a lower level of internal consistency.

\begin{tabular}{|l|c|c|}
\hline \multicolumn{1}{|c|}{ MFQ SCALE } & Pilot study & Asian studies \\
\hline Ought Self & 0.55 & 0.76 \\
\hline Ethnocentricity & 0.50 & 0.63 \\
\hline Parental encouragement & 0.67 & 0.79 \\
\hline
\end{tabular}

From the above information we see that aside from the scale of parental encouragement, which, at $a=.67$, although low, can be considered sufficiently reliable for use in the main study, a total of 3 scales did not obtain the desired internal consistency of $a=.70$. Among those was the ought L2 self scale targeting another of the core concepts of Dörnyei's theory. The remaining scale - Ethnocentrism at $a=.63$ was initially included, however, an alpha value of ,37 in the main study led to its elimination from further analysis.

The ought L2 self scale had one of the lowest reliability values at $\alpha=.55$ and this is disconcerting given that in all three original studies, the ought L2 self 
scale had very acceptable reliability (Japan (b) $-\alpha=.76$; China $-\alpha=.78$; Iran $-\alpha=.75)$. Given the lack of studies on the ought L2 self concept in Spain, we were cautious regarding the core concept we were attempting to tap into through the composite items and after further statistical analysis (See Brady 2014 for a detailed description of these), the decision was taken to include 2 further items in the scale reflecting the local pressure to certify English and one further item on peer pressure to learn English. The resulting 7 item scale was employed in the main study MFQ. (See Appendices I for the English and II for the Spanish versions).

The L2 learning experience as conceptualised by Dörnyei (2005, 2009) refers very broadly to engagement in informal and formal L2 learning without specifying temporal dimensions and, accordingly, the composite items making up the scales used in previous studies made reference to enjoyment of learning at different levels of education concomitant to the studies. However, language learning experiences have different temporal dimensions, as well as diverse contexts, e.g. formal versus informal learning, or supported tuition versus autonomous learning. In order to distinguish attitudes to past learning from current experiences and so examine the temporal aspect of learning experiences more in depth, it was decided at this point, to separate items making up the single Attitude to Learning scale in order to distinguish the ratings for past and present temporal dimensions. The scale containing items only referring to past experience at secondary school was labelled Attitudes to past L2 Learning $(\alpha=.78)$, and the scale containing three items that only made reference to learning experiences in present tense current attitudes to L2 learning scale $(\alpha=.73)$.

Table 5 shows the Cronbach alpha measure of internal consistency value of each of the multi-item scales calculated for the whole group and the three subsamples. Given the acceptable values we proceeded to analyse the data in order to address the RQs posed.

Table 5. Cronbach alpha internal consistency of main study MFQ scales.

\begin{tabular}{|l|c|}
\multicolumn{1}{|c|}{ scale } & whole sample $(N=519)$ \\
\hline INTENDED LEARNING EFFORT & .79 \\
\hline SELF RELATED FACTORS & .81 \\
\hline IDEAL SELF & .70 \\
\hline OUGHT SELF & .81 \\
\hline ATTITUDE TO PAST LEARNING & \\
\hline
\end{tabular}




\begin{tabular}{|l|c|}
\hline CURRENT ATtITUDE TO LEARNING & .73 \\
\hline ATtITUdINAL FACtORS & \\
\hline INTEREST IN L2 & .75 \\
\hline L2 CULTURAL INTEREST & .70 \\
\hline GOAL RELATED FACTORS & \\
\hline INTEGRATIVENESS & .80 \\
\hline INTERNATIONAL POSTURE & .72 \\
\hline INSTRUMENTALITY PROMOTION & .68 \\
\hline INSTRUMENTALITY PREVENTION & .76 \\
\hline AFFECTIVE FACTORS & .74 \\
\hline SELF-EFFICACY & .86 \\
\hline ANXIETY & .63 \\
\hline PARENTAL ENCOURAGEMENT & \\
\hline
\end{tabular}

The main MFQ was administered to the main sample of 529 college students grouped, into English Majors $(\mathrm{N}=176$, a primary and pre-primary education students $(\mathrm{N}=175)$ and an 'Other studies' subgroup $(\mathrm{N}=173)$ with no immediate tie to an L2 related profession. The resulting data was analysed using the statistical software SPSS 17.

\section{RESULTS AND DISCUSSION}

\subsection{SUMMARY OF MAIN STUDY FINDINGS}

To sum up our main findings under RQs 1,2 and 3 (for a full report see Brady 2019) we were able to establish that the ideal L2 self — visions of using English as a L2 in future professional and social contexts - appears to be a very relevant and significant concept across the sample and bears the strongest relationship with intentions to continue learning across the three subgroups. This finding coincides with those of the Asian studies as well as of most L2 MSS explorations (e.g. Busse 2013; Kormos and Csizér 2008; Lamb 2012; You and Dörnyei 2016). The ought L2 self scale, on the other hand, did not emerge as a significant figure either in the Education group as we had hypothesised, or in the sample as a whole. The participants overall rated external obligations very low on the scale $(M=1.43$, $S D=1.03)$ a fact that suggests that externally sourced impositions are not being recognised by any of the three groups examined. This finding coincides, for 
instance, with Kormos and Csizér (2008) who also found difficulty in identifying an ought L2 self dimension in their sample. Our attitudes to L2 Learning values, rating current and past dimensions of the learning experience showed a significant difference in the appreciation of each dimension of L2 learning in the sample with current attitudes reaching a significantly higher mean value than attitudes to past learning experiences for all three academic sub-groups. Table 6 shows the contrast of the mean value obtained in each scale. Non-parametric procedures were followed owing to the presence of outliers in the English major group.

Table 6. Scale means and Friedman Test contrast for Attitudes to past L2 Learning and Current Attitudes to L2 Learning.

\begin{tabular}{|l|c|c|c|c|}
\hline & $\begin{array}{c}\text { Attitudes to Past L2 } \\
\text { learning }\end{array}$ & $\begin{array}{c}\text { Current L2 learning } \\
\text { attitudes }\end{array}$ & $\mathbf{X}^{\mathbf{2}}$ & sig \\
\hline & Mean (SD) & Mean (SD) & & \\
\hline ENGLISH MAJOR & $2.67(1.35)$ & $4,32(.521)$ & 105.418 & .000 \\
\hline EDUCATION & $1.99(1.36)$ & $3,36(.997)$ & 74.907 & .000 \\
\hline OTHER STUDIES & $2.43(1.31)$ & $3,33(.906)$ & 56.529 & .000 \\
\hline WHOLE SAMPLE & $2.37(1.37)$ & $3.67(1.07)$ & 233.061 & .000 \\
\hline
\end{tabular}

The evidence obtained supports our initial hypothesis that learning English in compulsory education was somewhat negative. The Education students saw their past experiences at secondary school in a slightly more disfavorable light than the English Major and Other Studies cohorts. It is difficult to find an explanation for this other than the fact that being engaged in studies related to education involving analysis of methodologies, materials and teacher behaviour could have lead this group to analyse negative aspects of L2 learning (e.g. methodology or teachers) more deeply. A significant difference exists with regard to current attitudes to learning, although slightly less so in the Other Studies group. With regards to the relationship of these learning experience variables with future plans to engage in learning, Table 7 shows the correlation data. (Non-parametric analyses were used due to abnormal distribution in the English Major group). All three subgroups showed a relatively strong parallel affiliation between their current L2 learning attitudes and their intended learning efforts whereas the relationship with past learning experiences is considerably weaker. This is in itself a positive finding, suggesting that despite some previous negativity, L2 learning attitudes have changed. This was not the case for the Other Studies group who showed 
a stronger connection between negative past L2 learning experiences and their future intentions. This closer tie between past and future may be owing to a lack of current engagement in L2 learning given that Education students do have an EFL subject within their degree and this fact may be contributing to a change in attitude.

Table 7. Spearman's Rho correlations ${ }^{1}$ of L2 MSS core concepts with Intended Learning Effort.

\begin{tabular}{|c|c|c|c|c|}
\hline \multirow[b]{2}{*}{ L2 MSS SCALES } & \multirow[b]{2}{*}{$\begin{array}{l}\text { Whole } \\
\text { sample }\end{array}$} & \multicolumn{3}{|c|}{$\begin{array}{c}\text { Correlations with Intended Learning } \\
\text { Effort }\end{array}$} \\
\hline & & English Major & Education & $\begin{array}{l}\text { Other } \\
\text { Studies }\end{array}$ \\
\hline CurRent Attitude to L2 Learning & $.62 *$ & $.50^{*}$ & $.69 *$ & $67^{*}$ \\
\hline ATTITUDE TO PAST LEARNING & $.29 *$ & $.26^{*}$ & $.16^{*}$ & $.42 *$ \\
\hline
\end{tabular}

${ }^{1}$ For the interpretation of correlation coefficients, Cohen's (1988) guidelines (cited in Pallant, 2007) are followed: $<.29=$ small $<.49=$ medium $<.50=$ large .

*Correlation is significant at the 0.01 level (two-tailed).

Our findings on the three core elements of the L2 MSS in general coincided with findings in the Asian studies in that the Ideal L2 self was a) highly rated and b) showed a strong affiliation with intentions to expend effort in learning the L2. The ought L2 self emerged as a negative influence on L2 learning motivation and our first attempt at exploring the Learning Experience pillar of the L2MSS with a dual view on L2 learning attitudes was insightful in terms of local contextual information. Stakeholders in L2 education might benefit from an understanding that students may have negative views of previous L2 learning and wish to take steps in order to ensure positive experiences.

Now we look at how the various attitudinal, goal related and emotional variables fit into the $\mathrm{L} 2$ self system of the informants of the study.

\subsection{MOTIVATIONAL PROFILE OF SAMPLE ACCORDING TO PROFICIENCY}

Table 8 below shows the mean values obtained in the MFQ variables across the groups classified according to the general L2 competence the participants felt they possessed. Overall, we can see there was a progressive increase in the ratings of most variables according to perceived achievement with the exception being 
in the scale of the ought L2 self. This appears to denote a more heightened sense of imposition to learn in the lower achievers. Taking the scale of future intentions to expend effort in L2 engagement as a starting point for our analysis of the information, it seems that commitment to engage in L2 learning and/or improving language skills increases in proportion to perceptions of L2 achievement. Inversely, these findings suggest that the lower the current level of achievement, the weaker the commitment to engage in learning in the future. The ideal L2 self clearly exists and is rated positively by all groups but again is more pronounced in the case of higher level L2 users, perhaps an indication that this figure is more defined and readily available in the minds of the more proficient L2 students. These findings are not easily to contrast with those of previous studies because the subgrouping of perceived achievement did not feature in the Asian research. Indeed, as Al-Hoorie (2016) indicates, proficiency measures have been ignored in recent years in explorations of motivated behaviour thanks to a tendency to focus on attitudes and affect rather than L2 achievement. However, it is also the case that we are looking at perceptions of L2 achievement that may not necessarily coincide with reality.

The priorities in rankings of the attitudinal, goal related and affective motivational variables was quite similar across the six sub-groups, rating current attitude to learning, and self-efficacy among the most highly valued L2 related factors with goal-related factors of international posture, integrativeness and the instrumentality dichotomy closely clustered as a secondary set of influences.

The data on the ought L2 self suggests that a sense of imposition from external sources may intensify in proportion to lack of achievement in the L2. This L2 MSS figure was rated extremely low in the C1 cohort indicating that the more proficient users do not sense any imposition to learn the language from external sources meaning perhaps that the sense of duty has already been integrated into their self system and forms part of the ideal L2 Self. Our data suggests that perhaps an ought self is more easily detectable from the point of view of an avoidance of the pragmatic losses or gains (instrumentality prevention) as a result of L2 learning rather than attempting to pinpoint sources of pressure to social or family groups or individuals. Another external influence - that of family and parental encouragement, contrary to the Asian findings was ranked lowest in mean value of all the motivational factors possibly due to either an authentic lack of encouragement regarding English language learning in the family environment or, given that our participants were older than those in previous L2 MSS studies (e.g. Kormos and Csizér 2008; Lamb 2012) and therefore more distanced from the influence of parents once at college.

The size effect was quite large for many of the variables examined and this tells us that most of the factors examined are relevant and appear to bear a relation to 
Table 8. Mean values obtained in the motivational variables across English language proficiency subgroups.

\begin{tabular}{|c|c|c|c|c|c|c|c|c|c|c|c|}
\hline & \multicolumn{2}{|c|}{-A1 $(N=37)$} & \multicolumn{2}{|c|}{ A2 $(N=123)$} & \multicolumn{2}{|c|}{$\begin{array}{c}\text { B1 }(N= \\
114)\end{array}$} & \multicolumn{2}{|c|}{$\begin{array}{c}\text { B2 }(N= \\
145)\end{array}$} & \multicolumn{2}{|c|}{ C1 $(N=77)$} & \multirow[t]{2}{*}{$\mathbf{E t a}^{2}$} \\
\hline & Mean & SD & Mean & SD & Mean & SD & Mean & SD & Mean & SD & \\
\hline \begin{tabular}{|c|} 
INTENDED \\
LEARNING EFFORT
\end{tabular} & 3,23 & ,95 & 3,26 &, 85 & 3,91 &, 80 & 4,31 &, 63 & 4,33 & ,66 & .27 \\
\hline \multicolumn{12}{|c|}{ L2 MSS factors } \\
\hline IDEAl SELf & 2,98 & 1,27 & 3,01 & 1,18 & 3,75 & 1,00 & 4,30 &, 78 & 4,52 &, 59 & .28 \\
\hline Ought Self & 2,23 & 1,00 & 2,02 & ,98 & 1,43 &, 92 & ,99 &, 80 & ,71 &, 65 & .26 \\
\hline $\begin{array}{c}\text { CuRrent Attitude } \\
\text { to LEARNing } \\
\end{array}$ & 2,82 & ,84 & 3,06 &, 95 & 3,64 &, 77 & 4,22 &, 57 & 4,38 &, 50 & .35 \\
\hline $\begin{array}{c}\text { ATtITUDE TO PAST } \\
\text { LEARNING }\end{array}$ & 2,10 & ,88 & 2,70 & 1,08 & 3,02 & 1,01 & 3,13 & ,98 & 3,19 & 1,06 & .07 \\
\hline \multicolumn{12}{|c|}{ Attitudinal factors } \\
\hline $\begin{array}{c}\text { INTEREST } \\
\text { IN ENGLISH } \\
\text { LANGUAGE }\end{array}$ & 2,99 & 1,02 & 3,27 & 1,03 & 3,86 &, 77 & 4,31 & ,61 & 4,34 &, 55 & .27 \\
\hline $\begin{array}{l}\text { Cultural } \\
\text { INTEREST }\end{array}$ & 2,37 & 1,04 & 2,64 & 1,21 & 3,16 & 1,16 & 3,91 &, 942 & 4,31 &, 72 & .29 \\
\hline \multicolumn{12}{|c|}{ Goal-orientation factors } \\
\hline \begin{tabular}{|c|} 
INSTRUMENTALITY \\
PrEVENTION \\
\end{tabular} & 3,72 & 1,09 & 3,35 & 99 & 3,73 & 1,02 & 3,90 & ,95 & 4,08 &, 86 & .05 \\
\hline $\begin{array}{l}\text { INSTRUMENTALITY } \\
\text { PROMOTION }\end{array}$ & 3,68 & ,96 & 3,61 & ,80 & 3,92 & ,76 & 4,02 &, 76 & 4,05 &, 67 & .06 \\
\hline INTEGRATIVENESS & 3,12 & 1,08 & 3,23 & 1,09 & 3,51 & 1,02 & 4,01 &, 75 & 4,12 & ,66 & .14 \\
\hline $\begin{array}{c}\text { INTERNATIONAL } \\
\text { Posture } \\
\end{array}$ & 3,34 & ,82 & 3,51 &, 80 & 3,70 &, 76 & 3,95 & ,66 & 4,18 &, 59 & .11 \\
\hline \multicolumn{12}{|c|}{ Affective factors } \\
\hline AnXIETY & $\mathbf{1 , 9 6}$ & 1,12 & 2,26 & 1,15 & 2,76 & 1,27 & 3,09 & 1,32 & 3,49 & 1,29 & .12 \\
\hline Self-efficaCy & 2,19 & 1,05 & 2,85 & ,95 & 3,58 &, 75 & 3,97 & ,65 & 4,31 &, 59 & .38 \\
\hline $\begin{array}{c}\text { Parental } \\
\text { EnCOURAGEMENT }\end{array}$ & 2,54 & 1,37 & 2,93 & 1,27 & 3,31 & 1,28 & 3,24 & 1,31 & 3,12 & 1,4 & .02 \\
\hline
\end{tabular}


L2 achievement. Correlation data, however, can only indicate a relation but not the nature or direction of this. The motivational variables causing the highest degree of variation across the proficiency groups were a) the L2 self-efficacy scale at 38\% and b) current attitude to learning, which reached 35\% of the variation observed. This variation could indicate that attitude to learning and a clear sense of ability to learn the second language are highly relevant factors in L2 motivated behaviour. The ideal L2 self along with interest in the L2 and its cultural produce was found to be responsible for over $27 \%$ of variation across the subgroups according to level indicating the importance of these aspects of learning. On the other hand, the lack of variation in the instrumentality scales implies that the pragmatic benefits of learning English are recognised across the board regardless of perceptions of current L2 proficiency. Again, given the small effect size, we see that parental encouragement does not appear to distinguish higher or lower L2 achievers

\subsection{CORRELATIONS OF MOTIVATION VARIABLES WITH INTENDED EFFORT}

The correlations were calculated for the whole sample and then for the reported proficiency groups (see table 9) although, given the disproportionate number of participants in the A1 $(N=37)$ groups, these were not included as a subgroup.

Table 9. Pearson's correlations between motivational variables and intended learning effort across the perceived proficiency subgroups.

\begin{tabular}{|l|c|c|c|c|c|}
\hline & $\begin{array}{c}\text { Whole sample } \\
(n=529)\end{array}$ & $\begin{array}{c}\text { A2 } \\
(N=123)\end{array}$ & $\begin{array}{c}\text { B1 } \\
(N=114)\end{array}$ & $\begin{array}{c}\text { B2 } \\
(N=145)\end{array}$ & $\begin{array}{c}\text { C1 } \\
(N=77)\end{array}$ \\
\hline \multicolumn{7}{|c|}{ L2 MSS variables } \\
\hline IDEAL SELF & $.76^{* *}$ & $.65^{* *}$ & $.64^{* *}$ & $.45^{* *}$ & $.48^{* *}$ \\
\hline OUGHT SELF & $-.26^{* *}$ & $-.30^{* *}$ & -.19 & $-.27^{* *}$ & .12 \\
\hline $\begin{array}{l}\text { CURRENT ATTITUDE TO } \\
\text { LEARNING }\end{array}$ & $.62^{* *}$ & $.62^{* *}$ & $.60^{* *}$ & $.51^{* *}$ & $.49^{* *}$ \\
\hline ATtITUDE TO PAST LEARNING & $.36^{* *}$ & $.48^{* *}$ & -.16 & .18 & $.31^{* *}$ \\
\hline
\end{tabular}




\begin{tabular}{|c|c|c|c|c|c|}
\hline \multicolumn{6}{|c|}{ Attitudinal variables } \\
\hline CuLtuRAL INTEREST & $.56^{* *}$ & $.34^{* *}$ & $.43^{* *}$ & $.27^{* *}$ & $.22^{*}$ \\
\hline $\begin{array}{l}\text { INTEREST IN ENGLISH } \\
\text { LANGUAGE }\end{array}$ & $.71^{* *}$ & $.69^{* *}$ & $.56^{* *}$ & $.45^{*+*}$ & $.43^{* *}$ \\
\hline \multicolumn{6}{|c|}{ Goal-related variables } \\
\hline $\begin{array}{l}\text { INSTRUMENTALITY } \\
\text { PREVENTION }\end{array}$ & $.57^{* *}$ & $.45^{* *}$ & $.56^{* *}$ & $.31^{*+*}$ & $.41^{* *}$ \\
\hline $\begin{array}{l}\text { INSTRUMENTALITY } \\
\text { PROMOTION }\end{array}$ & $.54^{* *}$ & $.52^{* *}$ & $.49^{* *}$ & $.39^{* *}$ & $.56^{*+}$ \\
\hline INTEGRATIVENESS & $.63^{* *}$ & $.56^{* *}$ & $.65^{* *}$ & $.49^{* *}$ & $.41^{*+}$ \\
\hline INTERNATIONAL POSTURE & $.48^{* *}$ & $.39^{* *}$ & $.34^{* *}$ & $.28^{*+*}$ & $.23^{*}$ \\
\hline \multicolumn{6}{|c|}{ Affective variables } \\
\hline ANXIETy & .14 & -.10 & -.17 & .13 & .04 \\
\hline SELF-EFFICACY & $.59^{* *}$ & $.50^{* *}$ & $.30^{* *}$ & $.28^{* *}$ & $.48^{* *}$ \\
\hline Parental ENCOURagement & $.21^{* *}$ & $.23^{*}$ & .15 & .11 & $.23^{*}$ \\
\hline
\end{tabular}

**:Correlations are significant at the 0.01 level (two-tailed).

*Correlations are significant at the 0.05 level (two tailed).

With regard to the parallel relationships with intentions to continue engaging with the L2, the first values of note are the strong correlations of the ideal L2 self and attitudinal variables in general (Current attitude to learning, interest in the L2). It may be the case that these variables are tapping into a similar concept of intrinsic enjoyment of the language and the experience of engaging in its learning. Intrinsic enjoyment of the learning situation was highlighted in Kormos and Csizér (2008) who reported that enjoyable L2 learning experiences were important for their younger adolescent sample. Lamb (2012) also found the learning experience more relevant for rural and provincial learners, whereas Chen, Warden and Huang (2005) concluded that adult learners in China sacrificed the enjoyment factor and embraced the requirement to learn. The fact that our adult sample value L2 learning enjoyment may be a side effect of negative past L2 learning experiences and this may have implications for language teachers in that there is a need to provide enjoyable classroom experiences. 
The link with intended effort and the ideal L2 self although relatively strong in the lower proficiency groups, decreases to a moderate strength in line with the increase in L2 achievement. This finding is congruous with the argument that for an ideal L2 self to be effective there should be some distance between the actual L2 self and the L2 self guide (Dörnyei 2009; Henry and Cliffordson 2015). The higher L2 achievers in this sample are closer to an L2 ideal than the lower level participants, thus, perhaps now the sense of identification with this imaginary figure has lost strength. Thus, it seems to be the case that the visionary ideal is more strongly associated with future commitment to learn in the lower proficiency participants. Self-efficacy appears as stronger higher C1 cohort yet equally so for the beginners. This may suggest that the that the intermediate B1 and B2 students are aware that they have faults but that this will not deter them from engaging in L2 use and learning.

Regarding goal-related variables, integrativeness also features as a strongly related variable perhaps reflecting the traditional focus in Spanish EFL classrooms on British culture. Nonetheless, international posture also appears as relevant to intended learning effort across all the proficiency levels. In the $\mathrm{C} 1$ group, instrumentality promotion obtained the strongest relationship $(r=.56)$, with intentions to learn in contrast with other variables, instrumentality prevention showed a stronger relationship with the criterion measure only in the B2 proficiency group, which was, again, unexpected, given that they also would have reached an acceptable level of proficiency perhaps to be able to meet educational and professional requisites imposed by the government in Spain. However, it may be precisely this factor that is making them more aware of the need to avoid failure in the group. Although its relationship was still more intense than that of parental encouragement, which, along with anxiety, had a weak relationship with any future intentions to learn the L2.

\section{CONCLUSIONS}

We have attempted to replicate studies carried out in entirely different cultures to that of Spain for the first time and this will necessarily bring about aspects that can be improved on. We do not claim that the data obtained is representative of the university population in Spain. The findings in our study are limited to the students surveyed in the Region of Murcia and not to any regional or national university population. A very different picture may evolve in explorations of L2 learners in other regions of Spain. The MFQ and results are currently being submitted to further statistical analysis and Structural Equation Modelling, which will provide more information on the suitability of the scale items and enable us to learn more 
about the roles of the different motivation variables as precursors to motivated behaviour. As regards measurements of motivated behaviour, the criterion measure of intended learning effort, given its future orientation, does raise questions empirically as to its reliability as a valid measure. Only a longitudinal analysis could examine the extent to which L2 learners' promises and intentions do indeed convert to tangible learning goals and whether these efforts towards these are persevered.

Nonetheless, we feel that our contributions are valuable in the sense of providing a tested MFQ for other researchers to use and adapt for their own purposes as well as some interesting observations in our initial exploration of the L2 MSS in this sample. We have seen that the ideal L2 self is a relevant concept for L2 learners and teachers may wish to consider what they could learn from students' envisaged L2 users or even help those who find difficulty in generating this type of vision. In this sense, for instance Dörnyei and Hadfield (2013) have developed activities for language practitioners who want to help L2 students. Equally, the other variables we have discussed may become more relevant in L2 learning contexts, e.g focusing on international posture instead of a closed native speaker community.

Future studies may wish to examine some of the contextual issues raised more closely. For instance, more detailed examinations of L2 learning related variables may offer more information on the L2 MSS learning experience and given that the ought L2 self is still somewhat of an enigma in this and other contexts and a closer look at its nature and its relationships with instrumentality prevention might may shed more light on any energising influence this variable may have on L2 learning behaviour.

\section{REFERENCES}

Al-Hoorie, A. H. 2016. "Unconscious Motivation. Part II: Implicit Attitudes and L2 Achievement." Studies in Second Language Learning and Teaching 6 (4): 619-49.

Boo, Z., Dörnyei, Z. and S. Ryan. 2015. "L2 motivation research 2005-2014: Understanding a publication surge and a changing landscape". System 55: 145-157.

Brady, I. K. 2014. "Motivation in Spanish university students: A pilot study on the L2 motivation self system". Studies in Philology: Linguistics, literature and cultural studies in modern languages. Eds. G. Alcaráz-Mármol and M. M. JiménezCervantes-Arnao. Newcastle-upon-Tyne: Cambridge Scholars Press. 95-114. 
Brady, I. K. 2015. The Ideal and Ought-to L2 selves in Spanish learners of English. Unpublished PhD Thesis. University of Murcia.

Brady, I. K. 2019. "A multidimensional view of L2 motivation in Southeast Spain: through the 'Ideal Selves' looking glass”. Porta Linguarum 31: 37-52.

Busse, V. 2010. Foreign Language Learning Motivation in Higher Education: A Longitudinal Study on Motivational Changes and their Causes. Unpublished PhD Thesis. University of Oxford. <http://ora.ox.ac.uk/objects/uuid:4863fa6502e7-47e5-9258-6132e4ef8817>.

Busse, V. 2013. "An exploration of motivation and self-beliefs of first year students of German”. System 412: 379-398.

Busse, V. and M. Williams. 2010. "Why German? Motivation of students studying German at English universities”. Language Learning Journal 381: 67-85.

Chen, J. F., Warden C. A. and H. T. Chang. 2005. "Motivators that do not motivate: the case of Chinese EFL learners and the influence of culture on motivation". TESOL Quarterly 39 (4): 609-633.

Csizér, K. and Z. Dörnyei. 2005a. "Language learners' motivational profiles and their motivated learning behavior". Language Learning 554: 613-659.

Csizér, K. and Z. Dörnyei. 2005b. "The internal structure of language learning motivation and its relationship with language choice and learning effort". The Modern Language Journal 891: 19-36.

Csizér, K. and J. Kormos. 2008. "The relationship of intercultural contact and language learning motivation among Hungarian students of English and German. Journal of Multilingual and Multicultural Development 291: 30-48.

Csizér, K. and G. Lukács 2010. "The comparative analysis of motivation, attitudes and selves: The case of English and German in Hungary". System 381: 1-13.

Dörnyei, Z. 2005. The psychology of the language learner: Individual differences in second language acquisition. Mahwah, NJ: Lawrence Erlbaum.

Dörnyei, Z. 2009. "The L2 motivational self system”. Motivation, language identity and the L2 self. Eds. Z. Dörnyei and E. Ushioda. Bristol: Multilingual Matters. 9-42.

Dörnyei, Z. 2010. Questionnaires in second language research: Construction, administration, and processing. 2nd ed., London: Routledge.

Dörnyei, Z. and R. Clément. 2001. "Motivational characteristics of learning different target languages: Results of a nationwide survey". Motivation and second language acquisition. Eds. Z. Dörnyei and R. W. Schmidt. Honolulu: University of Hawaii. 99-432.

Dörnyei, Z. and K. Csizér.2002. "Some dynamics of language attitudes and motivation: Results of a longitudinal nationwide survey". Applied Linguistics 23: 421-62. 
Dörnyei, Z. and E. Ushioda, eds. 2009. Motivation, language identity and the L2 self. Bristol: Multilingual Matters.

Dörnyei, Z. and E. Ushioda. 2011. Teaching and researching motivation. New York: Routledge.

Dörnyei, Z., Csizér, K. and N. Németh. 2006. Motivation, language attitudes, and globalisation: A Hungarian perspective. Clevedon: Multilingual Matters.

Education First. 2014. "English Proficiency Report 2014". <https://media.ef.com/_/ / media/centralefcom/epi/v4/downloads/full-reports/ef-epi-2014-english.pdf>.

Education First. 2015. "English Proficiency Report 2015". <https://media.ef.com/_/ / media/centralefcom/epi/downloads/full-reports/v5/ef-epi-2015-english.pdf>.

Gardner, R. C. 1985. Social psychology and second language learning: The role of attitudes and motivation. London: Edward Arnold.

Gardner, R. C. and W. E. Lambert. 1972. Attitudes and motivation in secondlanguage learning. Rowley, Mass: Newbury House Publishers.

Hadfield, J. and Z. Dörnyei. 2013. Motivating Learning. London: Routledge.

Henry, A. 2011. "Examining the impact of L2 English on L3 selves: A case study". International Journal of Multilingualism 8 (3): 235-255.

Henry, A. and C. Cliffordson. 2015. "Impact of Out-of-School Factors on Motivation to Learn English: Self-discrepancies, Beliefs, and Experiences of Self-authenticity". Applied Linguistics 38 (5): 713-736.

Higgins, E. T. 1987. "Self-discrepancy: A theory relating self and affect". Psychological Review 94: 319-340.

Higgins, E. T. 1998. "Promotion and prevention: Regulatory focus as a motivational principle." Advances in experimental social psychology 30: 1-46.

Huang, H. T. and I. L. Chen. 2017 "L2 selves in motivation to learn English as a foreign language: the case of Taiwanese adolescents". L2 selves and motivations in Asian Contexts. Eds. M. Apple, D. da Silva and T. Fellner. Nottingham: Multilingual Matters. 51-69.

Islam, M., Lamb, M. and G. Chambers. 2013. "The L2 motivational self system and national interest: A Pakistani perspective”. System 412: 231-244.

Kanno, Y. and B. Norton, eds. 2003. "Imagined communities and educational possiblities: Introduction". Journal of Language, Identity, and Education 2 (4): 241-249.

Kim, Y.-K. and T.-Y. Kim. 2011. "The effect of Korean secondary school students' perceptual learning styles and ideal L2 self on motivated L2 behavior and English proficiency". Korean Journal of English Language and Linguistics 11 (1): 21-42. 
Kormos, J. and K. Csizér. 2008. "Age-related differences in the motivation of learning English as a foreign language: Attitudes, selves, and motivated learning behavior". Language Learning 582: 327-355.

Kormos, J., Kiddle, T. and K. Csizér. 2011. "Systems of goals, attitudes, and selfrelated beliefs in second-language-learning motivation". Applied Linguistics 325: 495-516.

Lamb, M. 2012. "A Self System Perspective on Young Adolescents' Motivation to Learn English in Urban and Rural Settings". Language Learning 62: 997-1023.

Mackay, J. 2014. "Applications and Implications of the L2 Motivational Self System in a Catalan EFL Context". The impact of self-concept on language learning. Eds. K. Csizér and M. Magid. Bristol: Multilingual Matters. 377-401.

Markus, H. and P. Nurius 1986. "Possible selves". American Psychologist 41: 954969.

Pallant, J. 2007. SPSS survival manual: A step by step guide to data analysis. Maidenhead. Open University.

Ryan, S. 2008. The ideal selves of Japanese learners of English. Unpublished PhD Thesis. University of Nottingham.

Ryan, S. 2009. "Self and identity in L2 motivation in Japan: The ideal L2 self and Japanese learners of English". Motivation, language identity and the L2 self. Eds. Z. Dörnyei and E. Ushioda. Bristol: Multilingual Matters. 120-143.

Taguchi, T., Magid, M. and M. Papi. 2009. "The L2 motivational self system amongst Chinese, Japanese and Iranian learners of English: A comparative study". Motivation, language identity and the L2 self. Eds. Z. Dörnyei and E. Ushioda. Bristol: Mulitlingual Matters. 66-97.

Ushioda, E. 2009. "A person-in-context relational view of emergent motivation, self and identity". Motivation, language identity and the L2 self. Eds. Z. Dörnyei and E. Ushioda. Bristol: Multilingual Matters. 215-228.

Yashima, T. 2000. "Orientations and motivation in foreign language learning: A study of Japanese college students". JACET Bulletin 31: 121-133.

Yashima, T. 2002. "Willingness to communicate in a second language: The Japanese EFL context". The Modern Language Journal 86i: 54-66.

Yashima, T. 2009. "International posture and the ideal L2 self in the Japanese EFL context". Motivation, language identity and the L2 self. Eds. Z. Dörnyei and E. Ushioda. Bristol: Multilingual Matters. 144-163.

You, J. and Z. Dörnyei. 2016 "Language learning motivation in China: Results of a large-scale stratified survey". Applied Linguistics 37 (4): 495-519. 
APPENDIX I

\section{FINAL MFQ ENGLISH VERSION \\ INTENDED LEARNING EFFORT (5)}

I am willing to make a great effort at learning English

I fully intend to spend time abroad to improve my English

I'm working hard to learn English

I think I am doing all I can to learn English

I will likely continue to study English after my degree

\section{ANXIETY (4)}

I would get very nervous speaking to a native speaker

I always think others will laugh at my English

If a foreigner asked me for directions in the street I would get quite nervous

I feel a sense of ridicule when I speak English

\section{ATTITUDE TO LEARNING (PRESENT) (3)}

I don't speak English for fear of making mistakes

Learning English is really interesting

I usually enjoy English lessons

\section{ATTITUDE TO LEARNING (PAST) (4)}

I learned a lot of English at secondary school

My experience in English lessons has always been positive

I loved English lessons at secondary school

At secondary school I had very good English teachers

\section{CULTURAL INTEREST (4)}

I like British and American music

I like to watch British and American TV series in English

I read novels, magazines, press, etc. in English

I like to watch films in English

\section{IDEAL SELF (5)}

I see myself living abroad and communicating in English

When I think of my professional career I see myself using English at work 


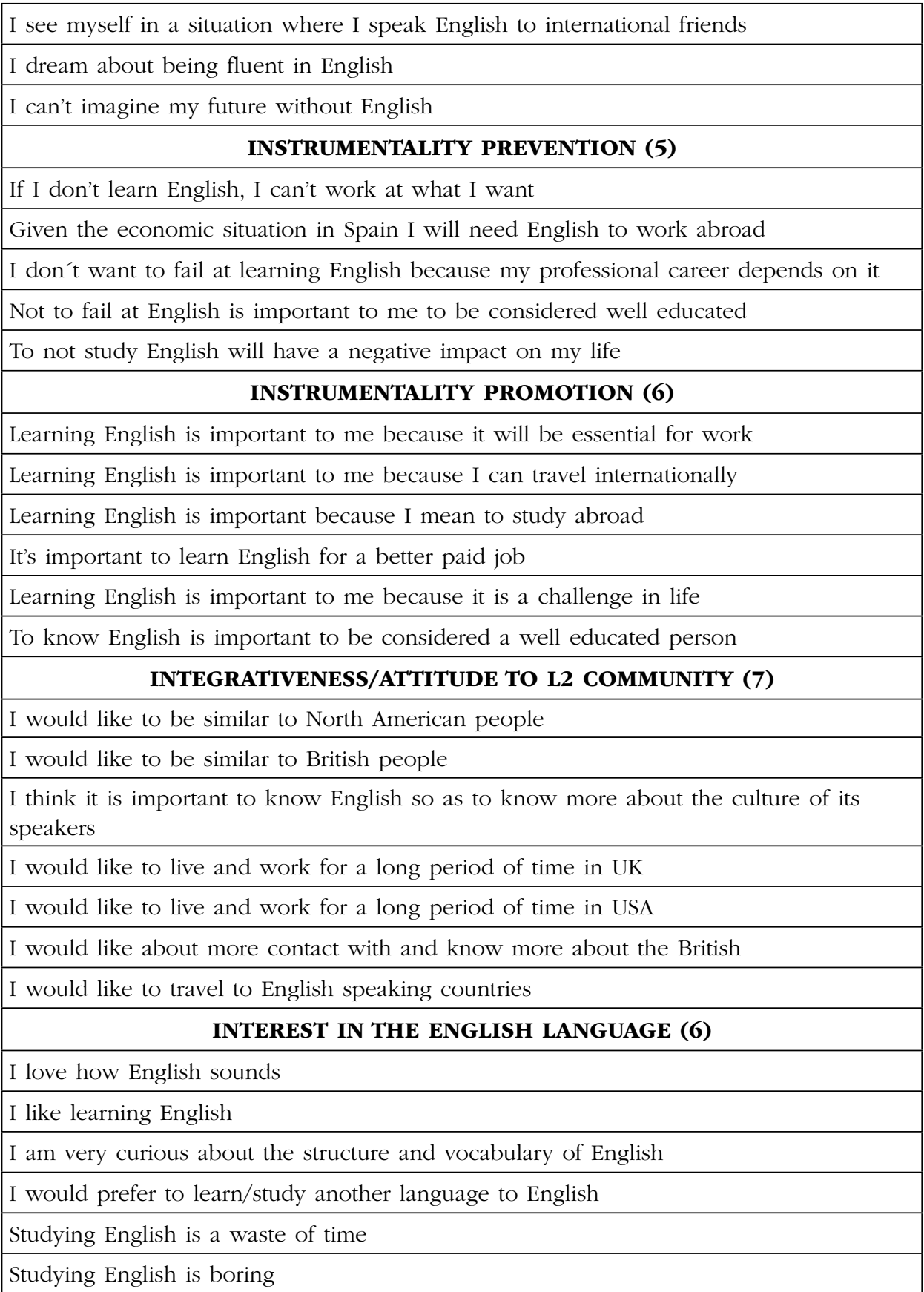




\begin{tabular}{|l|}
\hline \multicolumn{1}{|c|}{ INTERNATIONAL POSTURE (7) } \\
\hline I like to meet people from non English speaking countries \\
\hline I want to know English to communicate with non-native speakers \\
\hline I want to travel to countries other than English speaking ones \\
\hline I like northern European values and customs \\
\hline In general I like other cultures \\
\hline I like other cultures' values and customs \\
\hline I prefer to communicate in English with non natives \\
\hline \\
\hline I want to learn English because the people around me consider it important \\
\hline If it weren't for my loved ones I wouldn't learn English \\
\hline Actually, I feel obliged to learn English, it is not my desire \\
\hline My family think I should make more effort at English \\
\hline I need English for the official B2 certification to teach \\
\hline My friends have a positive influence on my desire to learn English \\
\hline All my friends talk about the importance of learning English \\
\hline \multicolumn{1}{|c|}{ PARENTAL ENCOURAGEMENT (4) } \\
\hline My parents have always encouraged me to learn English \\
\hline My parents have sent me to lessons since I was small \\
\hline My family think it is important to spend time abroad to improve one's English \\
\hline My parents would be equally happy with me if I never reached a command of English \\
\hline \\
\hline I find it quite easy to learn English \\
\hline If I make an effort I could reach a command of English \\
\hline I try to take advantage of chances to communicate in English \\
\hline English is very difficult for me \\
\hline
\end{tabular}


APPENDIX II

\section{MFQ SPANISH VERSION}

\section{INTENCIÓN DE ESFORZARSE (Criterio de medida) (5)}

Estoy dispuesto a esforzarme mucho en el aprendizaje de inglés

Tengo intención firme de pasar una temporada en el extranjero para mejorar mí inglés

Estoy trabajando mucho en aprender inglés

Creo que estoy haciendo todo lo que pueda para aprender inglés

Seguramente seguiré estudiando inglés después de la carrera

\section{ANSIEDAD}

Me pondría muy nervios@ si tuviese que hablar inglés con un nativo

Creo que los demás se reirían de mi inglés

Si un extranjero me pidiese indicaciones en la calle, me pondría nervios@

En clase tenía mucho sentido del ridículo al hablar inglés

\section{ACTITUD HACIA EL APRENDIZAJE (PRESENTE)}

No hablo inglés por miedo a cometer errores

Aprender inglés es muy interesante

Yo normalmente disfruto en una clase de inglés

\section{ACTITUD HACIA EL APRENDIZAJE (PASADO)}

Aprendí mucho inglés en el instituto

Mi experiencia en clases de inglés siempre ha sido positiva

Me encantaban las clases de inglés en el instituto

He tenido profesores muy buenos de inglés

\section{INTERÉS CULTURAL}

Me gusta la música británica y americana

Me gusta ver series británicas y americanas en versión original

Leo novelas, revistas y prensa, etc. en inglés

Me gusta ver películas en versión original en inglés

\section{EL IDEAL DEL YO}

Yo me puedo ver viviendo en el extranjero y desenvolviéndome con la gente en inglés Cuando pienso en mi futuro profesional, me veo utilizando el inglés en el trabajo 


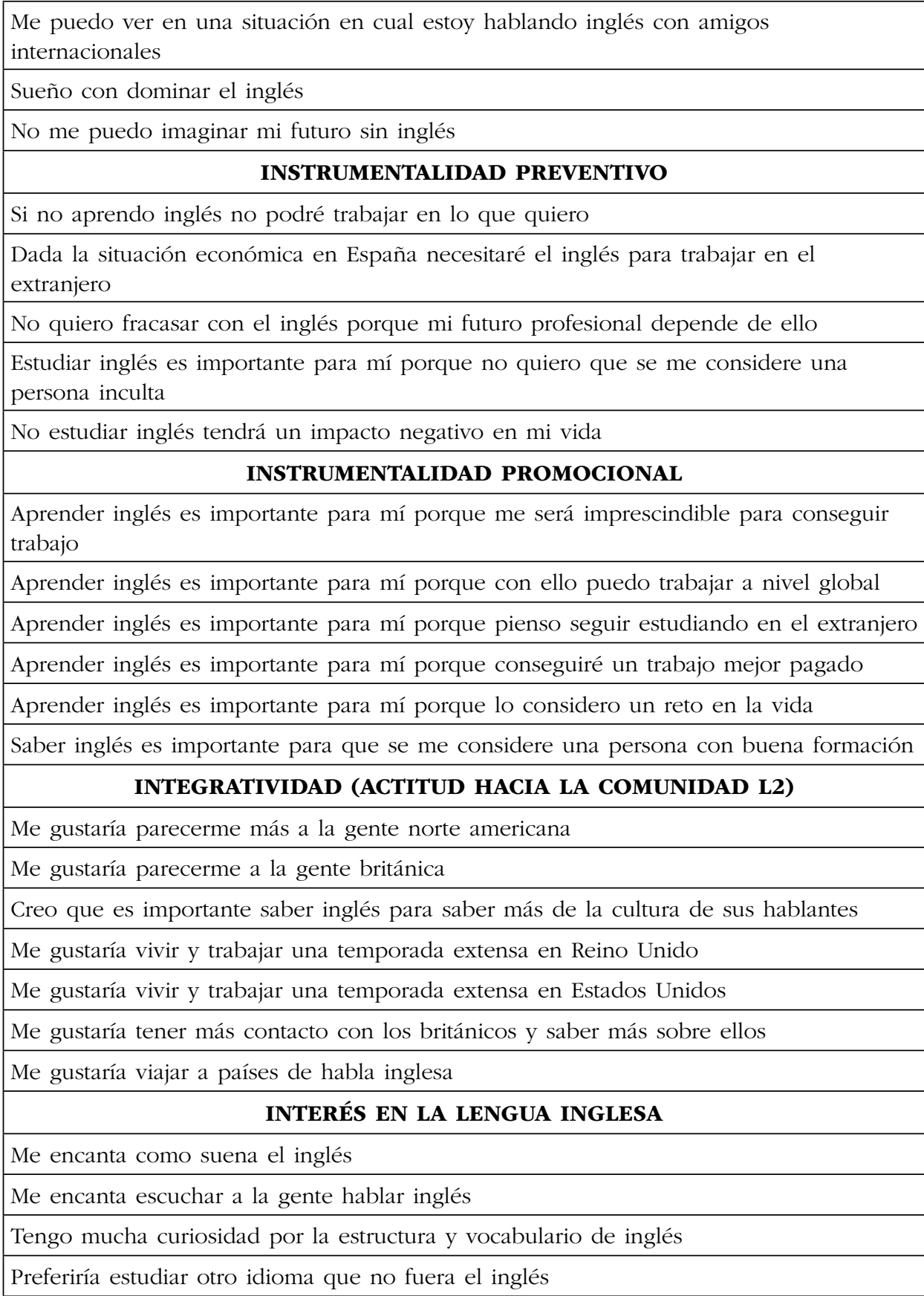




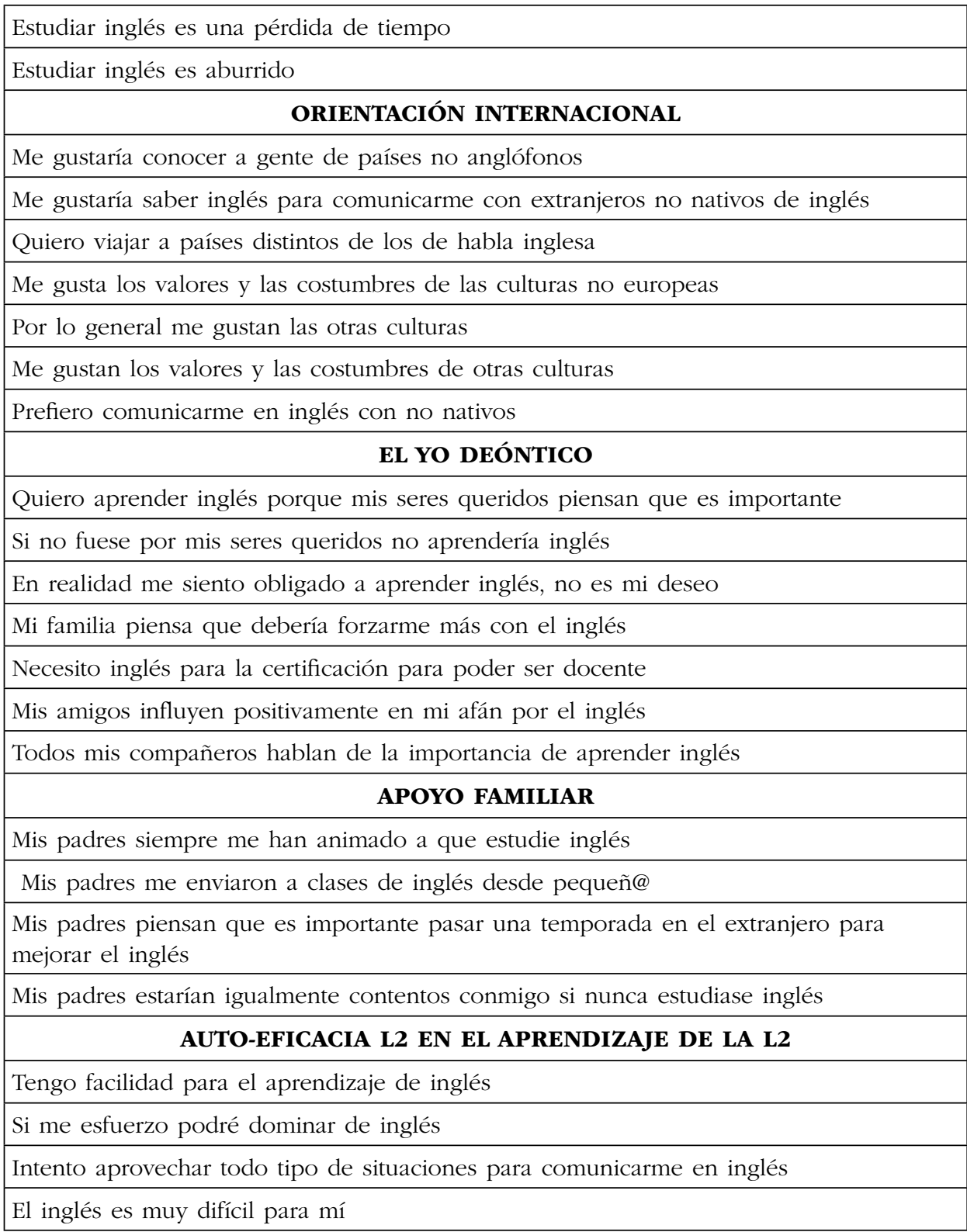

